\title{
A New Muslim Community: Children of Islam and Scotland ${ }^{\dagger} \ddagger$
}

\section{Stefano Bonino}

University of Trento, Faculty of Law, Via Verdi 53, 38122 Trento, Italy; stefano.bonino@unitn.it

† This work originally appeared in Muslims in Scotland: The Making of Community in a Post-9/11 World (Bonino 2017), www.edinburghuniversitypress.com.

$\ddagger$ This paper include existing Scottish data, studies, and literature on Muslims in Scotland with qualitative data specifically collected in Edinburgh between 2011 and 2013 through interviews with thirty-nine Muslims in order to understand the changing community patterns. The key research question is: have Muslim community structures changed in post-9/11 Scotland and, if so, how? Therefore, the paper offers a unique understanding of the reshaping of Muslim community structures in post- $9 / 11$ Scotland in relation to existing literature on Islam in Scotland and, more broadly, in Europe. The community was accessed through three very different mosques. The first one ('Mosque A') is an ethnically diverse and international mosque attracting a variegated pool of Muslims and is located in central Edinburgh. The second one ('Mosque B') is a Pakistani mosque catering for an ethno-culturally tight-knit community of older generation Muslims. The third one ('Mosque C') targets predominantly Scottish-born Muslims with a view to furnishing them with Scottish sociocultural tools of survival. The pool of respondents represented a collective body of diverse voices within the Muslim community who differed with regard to their ethnicity, gender, age, social class, and length of residence in Edinburgh. Most respondents (about two-thirds) were of South Asian background or heritage. The remaining respondents were Middle Eastern, African, British mixed, Scottish, and so on. Twenty-seven respondents were male and twelve were female. About half of the respondents were between 20 and 39 years of age and the other half was within the 40-60+ age group. Particularly those in the 20-39 age group, and generally slightly more than half of the total sample, were from a middle or upper-middle social class, while the remaining participants were from the working and lower classes. Participants had different experiences of settlement in Scotland and their length of residence in Edinburgh varied too, from as little as three years to as long as their entire life. Interviews were semi-structured and aimed to gather, among other themes, the changing community patterns in the post-9/11 period.

Received: 24 January 2019; Accepted: 5 March 2019; Published: 10 March 2019

\begin{abstract}
The experience of being a Muslim in Scotland today is shaped by the global and national post-9/11 shift in public attitudes towards Muslims, and is infused by the particular social, cultural, and political Scottish ways of dealing with minorities, diversity, and integration. The paper explores the development of Muslim communities in Scotland, highlighting the ongoing changes in their structure and the move towards a Scottish experience of being Muslim. This experience combines a sense of civic and social belonging to Scotland with a religious and ideological commitment to Islam.
\end{abstract}

Keywords: Islam; Muslims; Scotland; community; identity

The marriage between nation and religion in defining Scottish Muslims takes a distinctive form in changing notions and practices of community. Ethnicity and heritage culture are being sidelined in contemporary definitions of Muslimness. Today, being a Muslim is no longer coterminous with being Pakistani or Bangladeshi or Tunisian or Somali. The fact that younger generations are widely departing from their parents' and other relatives' experiences of migration to Scotland is not in itself a major discovery. Migrants tend to reproduce their sociocultural patterns in the new setting, in order to preserve their identities and sense of nationhood (Laliótou 2004). Moreover, family subcultures, as instilled by first-generation Muslims, sometimes problematically relate to mainstream society and can aggravate the social exclusion experienced by second- and third-generation Muslims (Hellyer 2007). 
In this regard, intergenerational changes and transformations are an obvious consequence of the deeply Scottish experiences of Scottish-born Muslims and of some younger migrants. Scottish Muslims' life perspectives and social practices are dressed up in tartan and play the music of Islam. Nowadays, being Muslim in Scotland is coterminous with being religiously and ideologically Muslim and being nationally and civically Scottish. And herein lies the novelty, as this has consequences for the dynamics of that collective aggregate of people of various ages, ethnicities, and social classes who affiliate with Islam, live in Scotland, and come together to form what is called a 'Muslim community'. Better, this should be called a new Muslim community. The new Muslim community equally gravitates around Islam and Scotland in ways that have never happened before. Undoubtedly, the marriage between Islam and Scotland is not free from obstacles. Yet, it feeds into powerful narratives of belonging to and unity with religion and nation, which colour the practices of the community of its children-the children of Islam and Scotland. Ultimately, despite the perils that it encounters and will continue to encounter, this marriage contains the potential to succeed. In the end, it will pave the way to a Scottish Muslim community, which will eventually contribute to shaping a new Scottish society.

\section{South Asian Transplant Rejected: Muslims at the Court of Scotland}

Notions and practices of tribalism, parochialism, and kinship still colour predominantly ethno-cultural understandings of community among older migrant Muslims, especially those of South Asian origin. Close local and transnational bonds of solidarity with members of the extended family and people from the same region or village are symbolically represented by 'Mosque B', a Pakistani mosque and cultural centre in Edinburgh that epitomises the tendency of South Asian Muslims to attend a place of worship with people who share the same ethnic origin (Sunak and Rajeswaran 2014). This mosque promotes a very ethnically and culturally focused sense of community, which centres on a lost Pakistan-a nostalgic sense of Pakistaniness that is kept alive by the practised memories of its attendees. These men (women at this particular mosque were out of the reach of the author) share not only the same ethnic and cultural roots but also a language and similar experiences of functional migration and partition ${ }^{1}$ from a land that they left in the 1950s and 1960s but still consider home. They quarrel over committee matters and they discuss Pakistani politics in Urdu. They talk about a Pakistan that is long gone but is still as fresh in their mind as it was fifty/sixty years ago. They enjoy gulab jamun, a popular South Asian dessert, during their ritual gathering in a tiny office after Friday prayer. They envision their daughters and sons being married to good Pakistani men and women from within their own clan. They keep in constant touch and visit their families in Pakistan. They form business partnerships and they share community activities, often at the mosque. Effectively, they are reliving Pakistani experiences within Scottish geographies.

Although not all of them necessarily reach out to broader society, they neither live in complete segregation nor represent the wider Muslim community. Certainly, they do not represent the experiences of the younger section of the community, especially those who are Scottish-born. The strong sociopolitical links with Pakistan that are maintained by the older Pakistani community across Scotland (see, for example, Colourful Heritage 2016), for example by paying homage to highly influential Pakistani political members who come to Scotland, are not displayed by the younger section of the community. In fact, younger Scottish Pakistanis consider recognition of notable Pakistani politicians to be of little importance, unless these politicians demonstrate concrete forms of engagement with their local Scottish Pakistani community (Qureshi 2006). Moreover, tribal, clan, and kin-based community structures and norms problematise the life and social choices of some younger Muslims who, while still placing the extended family at the core of their value system, are relatively culturally disengaged

1 The older migrant generation left Pakistan for Great Britain mainly for financial reasons. In fact, in the 1960s, a Pakistani migrant could earn a salary thirty times higher in Great Britain than in Pakistan and, thus, send good remittances back home (Ansari 2004). 
from South Asian mores. Effectively, they distance themselves from their parents' cultural and ethnic identities (Archambault 2007) and take up a stronger national and civic affiliation. Research has clearly demonstrated that tensions between the first generation of South Asians in Great Britain and subsequent generations, who are often considered to be 'caught between two cultures' (the ethnic culture of their families and wider British culture), have resulted in sociocultural tensions (Bolognani 2007, 2009). The cultural rift within orthodox and liberal sections of the Scottish Pakistani community at Glasgow Central Mosque is a case in point. Parental values and the role of the family as the provider of moral education are now considered to be out of step with the life experiences of second- and third-generation Muslims. Similarly, community leaders and mosques (Bolognani 2007) are deemed inadequate for the needs of new Muslim generations in a context of intergenerational instability and contested conformity to ethnic values (Wardak 2000).

However, the outlook of the older community members should not be pathologised but understood as the natural outcome of a strengthened in-groupness that helped them cope with a new cultural and social setting. Research respondents were well aware of this side of the story:

There are nuances here that need to be deconstructed and are unique to British life and do not emerge in the subcontinent. In some ways, it is a boiling pot that is unique only in [Great] Britain and you do not find it anywhere else, because the Bangladeshi community is not a routine Bangladeshi community here. Here, around 80 or 90 per cent of the Bangladeshi population is from Sylhet, which is the third-largest city in Bangladesh. For Sylheti people here in Great Britain, to marry a Bangladeshi, one first needs to be a Sylheti. It does not mean that the person cannot be from somewhere else, but the fact that one is not from Sylhet would be viewed as if the person were Pakistani or Indian. So here in [Great] Britain the Bangladeshi community is much more a unique society than the one that you would find there.

(Arif, Canadian Bangladeshi man in his early thirties)

Arranged and forced marriages are a prime example of how cultural and tribal norms work in practice at the expense of the younger generations' more nuanced life views, opportunities, and choices. For some scholars (Macey 1999), arranged marriages are pernicious because they function as a tool that legitimises the ongoing oppression of women under patriarchal structures through the alleged mandate of Islam. A more culturally aware analysis recognises that

The politics of marriage [is] embedded in customary notions of honour and shame, which surround the right to control the sexuality and reproductive powers of young people, particularly younger women's bodies, specifically by men and more generally by an older generation of migrants. (Werbner 2012, p. 108)

Arranged marriages, especially with a family member, constitute one of the most powerful ways of maintaining a connection with, and perpetuating the legacy of, the extended kin and tribal network or biraderi (Qureshi 2006). A testament to the persisting importance of intra-family marriages are the findings that about half of British-born Pakistanis marry an indigenous Pakistani spouse, often a cousin, and usually within a conventionally arranged marriage ${ }^{2}$ (Shaw 2001). Forced marriages are of a more legally and culturally problematic nature as, unlike arranged marriages, they entail coercion and/or lack of consent. The Forced Marriage Unit (2015) recorded 485 cases of possible forced marriages out of 1267 as involving people travelling to/from Pakistan ( 38 per cent), and a further 90 involving people going to/from Bangladesh (7 per cent), in the United Kingdom in 2014. Scotland accounted for 29 (2 per cent) of all cases. While forced marriages are not necessarily a Scottish-specific issue, they continue to be an under-reported practice and the real numbers are unknown (Bonino 2016).

2 This differs from a self-arranged marriage in which 'the girl and boy have courted secretly and have managed either to persuade or manipulate parents into arranging their wedding match for them' (Qureshi and Moores 1999, p. 324). 
Ae Fond Kiss (2004), directed by Ken Loach, is a cinematographic representation of young Scottish South Asians' cultural dilemma-should they pursue their passions when these betray family norms and expectations or should they bow to tradition? A masterpiece of social realism, the movie narrates the story of a young Scottish Pakistani man who brings his family to the brink of destruction when he defies an arranged marriage in the name of love-his love for an Irish Catholic woman (she herself also has a significant set of problems with the strict management of the Catholic school where she teaches). Looking back to reality, one of the film's leads, Glaswegian actor Atta Yaqub, confirmed at a post-screening panel discussion during Islam Awareness Week in Edinburgh the cultural pressures that young-both male and female-Scottish Muslims face. For the majority Pakistani community, these pressures can be traced back to expectations of moral and behavioural conformity at home and outside the domestic arena under the forces of individual and family honour or $i z z a t^{3}$.

Such pressures are well described by the stories of two Muslims living in Edinburgh, which are by no means isolated experiences in Scotland (see, for example, Carroll 1998; Sarwar 2016). After reaching legal age, Parveen, a Scottish Pakistani woman now in her mid-thirties, was sent to Pakistan by her parents to marry a cousin whom she had never met before. Leaving aside whether technically this was an arranged or a forced marriage-Parveen had to reluctantly consent to her parents' decision-this move can be seen as a means to reinforce cultural connections between 'home' and Scotland and bolster honour within the community of provenance. A couple of years later, Parveen returned to Edinburgh with her husband. The man obtained British citizenship a few years afterwards and subsequently divorced her. Similarly, Zakir, a British-born Pakistani man in his mid-forties, and his brother were both married off to Pakistani women. Zakir divorced years later and is still suffering from the financial and psychological costs of his parents' choice. His brother broke off relations with his family after what was, upon Zakir's admission, a forced marriage. The rationale behind Pakistani parents' decision to marry off their Scottish-born children to women from home is best left to Zakir to describe:

They say Pakistani women will be more obedient, know more about Islam, are more docile, and look after children, while they think that British women might not be so obedient. But Pakistani ones would bring their culture and language in to keep the tradition going. The British would be quite liberal in their ideas so they want to keep the traditions with Pakistani women. The practices are not changing. (Zakir, British Pakistani man in his mid-forties)

Therefore, transnational marriages feed into the older generations' manifestation of bonds to their homeland, since 'they improve the economic conditions of a further member of the biraderi (extended kin network) and reinforce the bridge with back home' (Bolognani 2007, p. 62). This system follows the Pakistani rural structure of life that was organised locally by tribes and not centrally by the state, and

One consequence was that people could not just marry whoever they wanted to. If they did, then over time tribal lands would be broken up by the rules of inheritance, and the economic base of the tribe, or biraderi (brotherhood), would be destroyed. This was one reason why children in rural Pakistan were often treated as the property of their elders and encouraged, or forced, to marry within the biraderi. (Kabir 2010, p. 43)

Obviously, transnational marriages do not exist in a cultural vacuum. Rather, they connect with broader biraderi-related norms within a hierarchical class-based social system that has been transplanted from South Asia into Scotland:

There is a very huge clan system within the Pakistani community. In amongst that system they divide themselves and look down on other people, which is a totally wrong thing. So if

3 Izzat formally rests on the male members of the family but effectively depends on how female members, as transmitters of cultural values and identity, are perceived by the community (Qureshi 2004). Izzat plays a crucial role in family and community cohesion and is enhanced by a variety of elements including high caste, a large number of male family members, being able to exert sociopolitical influence in Scotland and/or Pakistan, good educational and professional achievements, and a range of other factors such as generosity, honesty, wealth, and religiosity (Wardak 2000). (Qureshi and Moores 1999) 
they are looking down at their own people, you can imagine that they must be looking even further down on someone who is not Pakistani. There are people who came from Mirpur and those people were farmers. Another group were all landlords. All landlords. Of course those people look down on the farmers. Even now this kind of thing is in their mind and they pass it on to their children. But now the third generations do not bother about these things because it is too much hassle. (Adila, Kenyan Pakistani woman in her mid-forties)

Despite the fact that tribal connections tend to matter mostly to older migrants, according to Lewis (2007) there has been an increase in first-cousin marriages among younger British Pakistanis with the aim of reaffirming biraderi loyalties. For Lewis, this is an emanation of the more conservative attitudes of young British Muslims (aged sixteen to twenty-four) compared to their parents and grandparents. While some have certainly come closer to forms of orthodox Islam, younger Scottish Muslims have also shown diverse ways of being Muslim, which depart from strictly conservative religious or cultural principles and mores. Furthermore, Lewis recognises that younger people's attitudes towards biraderi are at least ambivalent:

The Pakistani community in [Great] Britain has been established here for over forty years. Now in their third generation, they face a crisis which threatens to undermine their future. At the heart of the problem lies the biradari, the extended clan network that governs all families and gives values and a sense of identity. Invisible to the outside world, a battle is taking place between biradari diehards and those who believe it has no place in modern British society. The youth are the casualties. (Lewis 2007, p. 46)

Arguably, retaining ethno-cultural mores within a sociocultural context that younger Scottish-born Muslims equate with Scotland rather than Pakistan/Bangladesh is uneasy. Such mores are often out of touch with young Muslims' daily experiences of Scottish life and might promote avoidance of, and seclusion from, cultural and ethnic intrusions within the fabric of the tight-knit tribal system. According to Hellyer (2007), second- and third-generation British Muslims have experienced an aggravated sense of isolation and alienation as a consequence of the contrasting requirements set by family subcultures and mainstream values, the lack of indigenous religious authorities, and sociopolitical discrimination. At the same time, shared norms and values passed down by families can take the form of a positive 'ethnic capital' and serve as an important tool through which one can overcome social class and/or economic disparities and achieve upward social mobility (Modood 2004; Shah et al. 2010). The system of biraderi is organised hierarchically, is influenced by caste, and performs a controlling and normative role (Bolognani 2009). Furthermore, it offers a sense of cultural and social belonging within community boundaries (Wardak 2000). Lastly, South Asians' intergenerational continuity in the form of social, emotional, and economic family ties, cultural enclosure, and self-sufficiency help maintain positive control of antisocial behaviour (Smith 2005). It is known that the family offers protection and guardianship and proves to be an antidote against crime and deviance (Sampson and Wilson 1995), along with other institutions of social control at various stages of life-school and peer groups during childhood; higher education, work, and marriage during young adulthood; and work, marriage, parenthood, and commitment to community in later adulthood (Sampson and Laub 1990). To sum up, rather than being an abnormality of the new Muslim community, traditional ethno-cultural norms and mores behave like electrons. They can occupy two different places at the same time, being both antidotes and cures for social illnesses, and obstacles to changing ways of being Muslim in Scotland.

\section{The Reality of Representation}

When Citizen Khan was first aired on BBC1 on 27 August 2012, one could only sit and wait for a storm of criticism to hit its creator and co-writer, British-born Muslim Adil Ray, and the British Broadcasting Corporation (BBC). In a climate of legitimate heightened sensitivities around post-9/11 media representations of Muslims, this first BBC South Asian sitcom (Adewunmi 2012), parodying a Pakistani family, might have felt unnecessary. Allegations of stereotyping South Asians and making 
fun of (Revoir 2012), ridiculing, and insulting (BBC News 2012) Islam ran high. In particular, a scene in which Mr Khan's younger daughter, Alia, who is wearing heavy make-up and has long hair, rushes to cover her hair with a hijab and pretends to be reading the Qur'an when her father enters the house, generated considerable heat (Huq 2013; Revoir 2012).

While the sitcom clearly built upon some cultural generalisations and essentialisations for the sake of entertainment, in the end it was 'British Muslims mocking their own communities, and how they're perceived by society [ . . , particularly by challenging] a myopic, indeed, racialist view of the Muslim family' (Saha 2013, p. 4). Abbas's (2013) concerns about Pakistanis being unduly stereotyped in the sitcom should not be dismissed. However, upper-middle-class Americans could have claimed similar grievances in the 1990s when Beverly Hills, 90210 depicted them as a group of insecure (Brenda), cocky (Kelly), troubled (Dylan), clownish (Steve), lazy, alcoholic, and unfaithful (pretty much all of them) privileged kids. Obviously, the concerns about the representation of Pakistanis and Muslims in Citizen Khan need to be located within the delicate post-9/11 sociopolitical context, which has augmented experiences, feelings, and perceptions of victimhood. Yet, paradoxically the sitcom may have promoted normalised social views towards Pakistanis by portraying them as ordinary citizens who conduct ordinary lives with a flavour of cultural and religious distinctiveness.

Going beyond the satire and the potential underlying cultural 'subversiveness' of the comedy, Citizen Khan highlights some of the tensions that ongoing developments in identity, family, and forms of community have brought into the lives of British and Scottish Muslims. The character of Mr Khan, in his proud and rather patriarchal form, resembles some of the older members of the Scottish Pakistani community. This is especially evident in the ways in which ethnic and cultural memories shape ideas, beliefs, and practices of community in the Scottish context. Mr Khan also represents the typical Muslim migrant who comes from a country and a region where Islam is a taken-for-granted cultural, political, social, and economic component of society (Lewis 2007) with little space for discussion, change, or transformation.

Like many Scottish-born Muslim women, Shazia, Mr Khan's older daughter, places marriage and family at the core of her life. However, she maintains an independent vision of life, which considers the broader context through negotiated Scottish and Pakistani practices. Finally, Alia, the most interesting and controversial character, features deeply intricate psychosocial elements that lead her to live a 'double life'. In front of her father she portrays herself as-to use Mr Khan's words-'a very good Muslim girl'. She covers her hair with a hijab and pretends to either read the Qur'an or do homework whenever her father is in close proximity. She presents herself as a morally irreproachable Muslim girl to be in her father's good books and obtains his permission to engage in social activities that are astutely covered under religious pretexts-for example, when she asks for money to go on a study trip to Turkey, which turns out to be a party holiday. When her father is away or when she is shielded by the secrecy of her mobile phone, Alia reveals her inner self: a 'Westernised' young girl who wears heavy make-up, tight jeans, and bright tops and craves mainstream entertainment, such as going out in mixed environments, partying, or dating boys. Alia represents the more liberal, 'Westernised', 'rebellious', and sexualised Muslim girl that has a counterpart in Scottish-born Parveen.

A prime example of a 'Scottished' Muslim, Parveen has lived a life juggling family mores, community expectations, and wider social opportunities. In many ways, Parveen, her sister and many of her friends conduct 'double lives' and refine cultural navigation skills (Qureshi 2006) that allow them to save face within their (extended) family and enjoy Scottish social life at the same time. While they maintain a facade of moral and religious purity in front of their families (especially their fathers), ${ }^{4}$ Parveen and her friends do not refrain from entering the 'forbidden' spaces of clubbing, gambling, drinking, and casual relationships. Parveen's nights out clubbing and her trips down to England to

4 Whether families consciously or unconsciously decide to turn a blind eye to the social experiences of their children is unclear, although informal conversations with some older members of the community suggest that they are at least aware of the younger generations' redefinition of acceptable social practices and engagement in culturally 'reproachable' activities. 
see one of her previous boyfriends were covered up through white lies that would prevent any family interference. Modern technologies and the far-reaching possibilities that the new social media offer in expanding human interaction outside the physicality of traditional face-to-face communication provide opportunities to redefine individual lives and the boundaries of community structures through negotiations and the integration of Scottish influences. While these cultural negotiations might not be part and parcel of all younger Muslims' experience of social life, surely they signal an internal awakening and the acceptance of Scottish elements that lead to the shaping of a forward-thinking Scottish sense of Muslim community.

Some Scottish Muslims try to escape parental restrictions on movement, which limit young women's friendships with white people (Qureshi and Moores 1999). In this sense, they are not immune from external social 'temptations' and might explore deeply sexualised spaces, such as nightclubs, where gendered relations are often based on the intoxication of the senses, a loss of personal control, and high physical contact. As both informal conversations and, particularly, personal acquaintanceship with younger Muslims in town suggest, several members of the community can now be found mixing in social activities with non-Muslim people and enjoying 'forbidden pleasures' ${ }^{\prime 5}$ that would be stigmatised by many in the Muslim community. It is hard to quantify the extent of this trend as not all young Muslims partake in, or condone, these behaviours. Yet, the new Muslim community is being reshaped around Scottish patterns of acculturation and mixed socialisation that defy traditional understandings of Muslimness through the morally pristine and ethno-culturally coloured lenses of the migrant community.

More broadly, this reflects changing patterns of socialisation, life opportunities, and choices available to Scottish-born Muslims as opposed to their parents and the ways in which the former have managed to doubly cross ethno-cultural boundaries by extending their own networks to both different Muslim ethnic constituencies and Scottish society at large:

In the Pakistani community and in the Arab community you will see that older people tend to stay among themselves because there is no such common ground to meet. I see that things are changing now, because kids are growing up and they want to meet with different Muslims, not only with the Pakistanis. When I came here the logic was more about which part of Pakistan you come from and then people would meet with each other accordingly. Now the kids are growing up and meeting with each other at university, college, or school. That is why, when they grow up, they are more Scottish than they are Pakistani. (Muna, Pakistani woman in her early forties)

This changing sociocultural landscape will continue to intensify generational differences and to paint Muslims' experiences in tartan colours. In particular, it will provide further evidence for the argument that intergenerational changes have broken the traditional family system due to a much lower commitment to the preservation of the clan's bloodline, prestige, and honour (Lewis 2007). The constraints of biraderi and community-related pressures still exist. Yet, the new Muslim community is quickly sidelining ethno-cultural values to embrace a wider commitment to both Islam and Scotland.

\section{From Local Life Choices to Global Belonging}

As the sociocultural landscape of Great Britain developed and registered an increase in young students' participation in higher education of over 20 per cent from the mid-1990s to the late 2000s (Higher Education Funding Council for Higher Education Funding Council for England 2010), Scotland was not left behind in this process of educational massification. A recent study shows that Muslim families in Scotland (and England) have quite high educational aspirations for their

5 While some drink, Muslims are still the least likely religious group (2 per cent as opposed to 14 per cent of Hindus, 16 per cent of Buddhists, and 32-40 per cent of the various Christian faith groups) to drink (or admit to doing so) at hazardous or harmful levels (Whybrow et al. 2012). 
children ${ }^{6}$ (Weedon et al. 2013), who tend to have ambitions other than the mere pursuit of money. However, despite Weedon et al.'s optimistic findings, there exist tensions with family members who still prioritise financial stability over purely educational achievements:

Younger people are a bit more ambitious. Older generations are much less ambitious and not even encouraging the younger generations to move ahead. At best what they would say is, 'Do what you want-if you want to become successful, go for it,' but I have never seen them saying from a child's young age, 'You can be a doctor, you can be an engineer.' [ . . . ] People would not go that far if it means that they were going to affect their family bonds. The idea is that you should do what you want for your fulfilment-social happiness is good-but there is also a certain element of financial security that needs to be there to impress your parents and your family. It is a balance between the two. (Arif, Canadian Bangladeshi man in his early thirties)

Other Edinburgh Muslims have similar stories. One such person is Zakir. While his sisters were withdrawn from school at the ages of fourteen and fifteen, his dreams of going to college and becoming a lawyer were destroyed by his parents' hostility. First, he was pushed to work as a repairman and then he was bought a post office to placate his intellectual aspirations. Zakir, now in his mid-forties, is finally studying for a university degree while teaching English. He reflected on his experience and on younger Muslims' changing experiences over a cup of tea at his rented flat:

My parents did this because they had a village mentality. However, nowadays most parents would let their children be educated. I was the first one in my extended family to go to university. Now my nephew goes to university. Another nephew is an accountant in London. The other one is a teacher. Even my niece went to do business studies. This is because they saw someone do it. Otherwise they would have no aspiration to do it. I did it and inspired people in my family. People of my generation are pushing children to get a good education. (Zakir, British Pakistani man in his mid-forties)

While family pressures may hamper the full realisation of young Muslims' goals, it is true that a number of Muslim families, and non-Muslim families alike, have an understanding of life goals that differ from those of their own children. This is substantiated by research on minority ethnic enterprises in Scotland (Deakins et al. 2005), which found that some members of the younger generation, especially South Asians, tend to be reluctant to continue their family businesses because they wish to choose career paths of their own. The life choices of the older members of their families are not only restricted by a different view of educational and career prospects. These choices also influence their reduced participation in Scottish society and in global politics, in which, by contrast, younger Muslims have been immersing themselves:

If there is a protest in town run by Muslims, in order to join it, they have to close their business. You will not see a shop run by a Muslim close a single day. Even if it is the biggest celebration for Muslims, for example Eid, they do not even shut their business on that day, thinking that they might lose revenue. [ ... ] It is only from my generation onwards that we have different perspectives, because the elders are mostly concentrated on their financial issues. They decided to bring up their children in the best way and they had a lot of hard times in their life. You can see some of the corner shops opening at 6 a.m. and not closing until 10 p.m. The money that they make is nothing compared to an educated person who has an office job. But they worked hard to raise their family. This is the reason why they

6 This resonates with research on South Asians in England and Wales, according to which migrant families instill in their sons and daughters a sense that education is important and that academic success should take precedence over youth recreational culture and other similar pursuits (Modood 2005). 
came to [Great] Britain. The people that you will see in protests are Muslims who are mostly educated and are aware of right and wrong. (Yasir, Pakistani man in his mid-twenties)

Undoubtedly, younger Scottish Muslims have developed different survival skills and life goals from those of their families. With money not necessarily being their primary goal, education and career prospects have become the benchmark by which they compare their success to that of the wider non-Muslim population. While this may not apply to all of them, the aspirations of many young Scottish Muslims partially override core, traditional community values and expectations, such as gaining immediate financial stability, raising a family at an early age and reproducing kinship connections. Instead, they gravitate around Western goals of climbing the socio-economic ladder through middle-class means, such as education and hard work.

Young Scottish Muslims are engaging with the global world and are becoming more sociopolitically aware and active than their parents. This links with the formation and the development of a mix of religious, ideological, and political Muslim identities that have been shaped through the Rushdie Affair and the more recent global, political reaction to 9/11 and that have local ramifications in everyday Muslim lives. Yasir's belief that those Muslims who join protests are predominantly those who are educated and aware of social justice and ethical issues is not just a sweeping generalisation. Instead, it is supported by the evidence of an increase in civic and political engagement of the British Muslim elite-that is, 'a group of people-young students and professionals—who have or potentially have access to symbolic and economic capital conferred through entry into higher educational institutions and professions' (Edmunds 2010, p. 218; Peace 2015c). In Edinburgh a considerable proportion of Muslims who join local anti-war protests, pro-Palestine campaigns, and charitable causes are young, middle-class, educated, and sociopolitically aware. This refutes the assertion made by Hopkins (2007b) that young Muslims are detached from politics partly as a result of conformity to a narrative of masculinity ${ }^{7}$ that conceives of politics as feminine and therefore soft. Instead, a global sense of Muslimness, which has been shaped by international events and feelings of both unity and victimhood, is played out locally through the display and deployment of a trans-ethnic and socially cohesive community. Arguably, the political mobilisation of Scottish Muslims qua Scottish Muslims predates September $11 .{ }^{8}$ Community responses both to the Rushdie Affair in 1989 and in opposition to the involvement of the United States and the coalition forces in the First Gulf War in 1990 (Maan 2014) are telling examples. However, September 11 has increased the political activity and confidence of Scottish Muslims who, less than two months after the attacks on the Twin Towers, on 30 October 2001, could be seen taking to the streets of Glasgow, alongside the Campaign for Nuclear Disarmament and the Stop the War Coalition, to protest against the invasion of Afghanistan by American, British, and allied forces (Maan 2014).

Islam is the social glue that keeps together different cultural, ethnic, and generational constituencies within a model of unity and relative homogeneity, not only of religious affiliation but also of ideas of social justice, human rights, and ethics. Therefore, while single individuals play out their religiosity differently, Muslims' group identity is predicated on, and maintained through, Islam:

There are many different Muslims in the world and we are not going to have the same goals in life, we are not going to have the same interests but there is one thing that draws us together and it is that we believe in the one God and the Prophet Muhammad (Peace Be Upon Him) as the last messenger. So we have got that in common. So I like when I am going out with my Muslim friends, I like that we all make the effort to make sure that we pray, and if we are fasting we all know that we are fasting. (Rabab, Scottish Pakistani woman in her late twenties)

7 While the author remains unconvinced by these arguments, readers may wish to refer to other work by Hopkins (2009) on the alleged crisis of masculinity among young Scottish Muslims.

8 For an analysis of British Muslims' political mobilisation and activism, see (Peace 2015a, 2015c). 
'Charity Week', organised by Islamic Relief UK across Great Britain, is testimony to both the power of Islam to bring together different Muslims and the ideological and solidaristic nature of 'doing Muslim community' in practice. When Muslims gather in Edinburgh for the closing dinner and auction, one can normally see over 100 people, mostly Pakistanis in their twenties, thirties, and forties, some children and a small number of elderly people in attendance. This broadly reflects the demographics of Muslims in Scotland but also the increased sociopolitical mobilisation of younger generations. The event is normally gender-segregated, although towards the end barriers tend to break down and some men and women engage with one another. Attendees are dressed formally and elegantly, as one would expect at such an event, but even more so given the important role that honour plays within a South Asian majority community.

Requests for donations not only leverage Muslims' sense of social responsibility for those in conditions of disadvantage but also reinforce a publicly projected sense of performative morality and solidarity. In a post-9/11 context of heightened feelings of global victimhood, Scottish Muslims may well enjoy their 'privileged' life but do not completely forget the needs of fellow Pakistanis. Over the three-course dinner, touching videos capture people's emotions, while an eloquent imam plays on Islamic teachings to urge Muslims to empathise with the suffering of orphans. This has the double effect of reiterating one's religious and moral duties to donate (zakat) and appealing to one's feelings of empathy, diasporic guilt ${ }^{9}$, and global connectedness. This is not only a performative display of active belonging to the imagined—or, as Roy (2007) would say, 'virtual'—global Muslim community (umma), whose increased affiliation has been promoted by global events, such as the wars in Afghanistan and Iraq ${ }^{10}$ (Hussain and Bagguley 2012). It is also a direct manifestation of a 'glocal' community which is conceived globally through ideas of what a Muslim is and should be but is played out locally through practices that bind individuals to one another. To put it in Roy (2004) words, it is a two-level community: the universal, global, and ideal community of all Muslims as based on the notion of the umma, and the local or national congregations of Muslims framed within the social and legal structure of a given society.

As the Syrian civil war had brought fear and destruction for about a year, the Edinburgh Muslim student society decided to organise a solidarity event open to the public in 2012. Unlike the previous relief activities in support of those affected by the Kashmir earthquake in 2005 (Archambault 2007) and the Pakistan floods of 2010 (Sarwar 2016), or even earlier solidarity events organised in support of Pakistan in the 1970s (Maan 2014), there was no sense of a community gathering based on shared ethnicity or personal connections with Syria. Instead, the Syrian solidarity event evidenced the commitment of predominantly younger Muslims to unite and demonstrate support for Muslims abroad by linking through their shared sense of global identity. It was a symbolic demonstration of what 'a global Islamic consciousness unbounded by geography' (Kundnani 2014, p. 38) looks like. Furthermore, this event displayed the Scottish Muslim community's potential for global and local mobilisation and unification in the face of world political events and conflicts.

Emotions, ideology, religion, and solidarity mix together to shape and project an image of local and global Muslim homogeneity that goes beyond different geographies, ethnicities, and cultures. This partly rejects the argument that Muslims in the West have paid lip service to the umma but committed to communities in a Western and secular manner (Roy 2004). It also partly refutes the idea that 'much of the negotiation of difference occurs at the very local level, through everyday experiences and encounters' (Amin 2002, p. 959; quoted in Hopkins (Hopkins 2007b, p. 1129)). Instead, Scottish

9 This refers to the economic conditions of migrants being better off than those of their fellow countrymen who decided to remain in their home country.

10 British Muslims have historically been involved in the anti-war movement from the original foundation of the Stop the War Coalition (StWC) and through and after the invasion of Afghanistan and Iraq. On 15 February 2003, the StWC protest march in London against the war in Iraq featured many British Muslims in what has been their largest mobilisation so far (Peace 2015b). 
Muslims are deeply committed to the ideas and practices of the umma and connect with fellow Muslims across the globe. Often in the absence of a shared language, heritage, and culture, it is Islam as a religion, and sometimes as a political ideology, that brings together such distinct Muslim communities. This does not discount the fact that Scottish Muslims can also be equally committed to the Scottish nation, given that their group identity is a direct emanation of their individual identities. In fact, while being Muslim at heart, these men and women are also strongly and proudly Scottish. When these events are over, Muslims live ordinary lives as ordinary Scottish citizens. Here the joys but also the pains begin to emerge.

\section{Negotiating Social Bridges}

While embracing Scottishness as a marker of belonging offers Muslims a sense of place and a badge of cross-cultural unity, the negotiation of diversity in daily social life is not always free of obstacles. Arguably, the socialisation of young Scottish-born or 'Westernised', recently migrated Muslims into the daily Scottish system of education, entertainment, and wider collective social spheres has broken cultural understandings of community boundaries as defined by the practices, mores, and norms of its older, ethnic (predominantly South Asian) section. As other studies (Kabir 2010; Lewis 2007) have highlighted, migrant communities tend to colour their religious understandings and practices with ethnic and cultural traditions. In itself, this is a mutable process, as today's older generations, who castigate Scottish-born Muslims for engaging in unorthodox activities such as drinking and premarital sex, were guilty of similar 'sins' during their settlement in Scotland. Zakir highlights this moral shift:

My father used to be a heavy drinker. But Ramadan was observed. He used to go to the Friday prayers. Most of the precepts were followed, like eating halal meat and so on. Wear a hat! [... ] These are people from the old guard, very intolerant of the younger ones because they think that they are not doing things right, like playing football or snooker. They think that this is corrupt Islam or not pure Islam because it is not their school of thought. You will see the old people wearing hats in the front rows during Friday prayers! (Zakir, British Pakistani man in his mid-forties)

Visiting 'Mosque B' on a Friday afternoon corroborates Zakir's points. At 'Mosque B', or at any other traditionally Pakistani mosque in Scotland, a curious visitor could spot a good number of Muslims who are each sporting a topi, the typical South Asian cap, in a climate strongly infused with Pakistani culture. This ranges from traditional clothes to heated discussions in Urdu, pictures of breathtaking Pakistani landscapes hanging on the office walls, and the ritual of eating traditional sweets after prayer. Undoubtedly, visiting this small mosque is a powerful cultural experience, which draws attention to a section of the Muslim community that remains united through a nostalgic sense of Pakistaniness suspended in space and time. At the same time, it acts as a reminder of the barriers that older generations still face in taking full part in public life. A generalised lack of language fluency and low levels of interest in becoming part of the broader Scottish community, compared to their younger counterparts, once again point at both their functional migration and their strong, romantic attachment to their home country (Bolognani 2007). This follows Lewis (2007) argument that Muslim migration to Great Britain not only encompassed the need to adapt and live in equality and fraternity within a non-Muslim country but also included a major shift from a rural society to an urban society where diaspora communities attempted to recreate a clan-based organisation.

Turning back to Zakir's words on the ongoing shift of moral understandings of Islam along cultural lines, documentary sources (BBC2 1966) demonstrate that (predominantly South Asian) Muslim migrants in Bradford had already started incorporating some adaptive approaches and British tools of socialisation, including moderate drinking, within their own weekly social routines in the 1960s. Equally, a film representation of a mixed English family led by a Pakistani migrant (Mr Khan) in Salford, East is East (1999), directed by Damien O'Donnell, shows some of the English-born sons having already incorporated similar British tools of socialisation, including drinking, clubbing, and quite relaxed 
sexual attitudes, in the early 1970s, a context in which 'the film highlights the paradoxical nature of identity inevitably slipping away between two worlds [that is, the fixed world of the Pakistani father and the fluid world of his English-born Pakistani sons]' (Zapata 2010, p. 185). It is therefore peculiar that older Scottish Muslim migrants project a highly moral and ethno-culturally grounded vision of personal development and social integration, which employs traditional cultural understandings of Islam, as a tool for establishing norms of behaviours and practices.

This is even harder to reconcile with the more nuanced and complex social experiences of the younger section of the community. Such experiences mix nation, religion, and culture in defining the fuzzy contours of Muslimness. Yet, while rejecting some of their home cultural norms, younger Scottish Muslims do not take up all Scottish socialisation practices by default. The 'clash of two cultures' thesis is less black and white than one might believe and involves a degree of personal and collective choice and sorting. In a way, the number of freedoms that Muslims believe Scotland and, more extensively, Great Britain (see Suleiman 2009) offer allows a pick-and-choose approach to national, ethnic, and religious elements, selecting those that marry with one's hierarchy of norms and values:

I do not have to adopt Scottish culture. Let's say that drinking is part of the Scottish culture. I do not have to do it. Ceilidh dance is part of the Scottish culture. I do not have to do it. They do clash with Islam. It is a big clash but I do not have to do it. But with regards to the Pakistani culture, I live in a Pakistani family and my family is very open-minded but still when it comes to rituals, there is a hard-core Pakistani culture in there. We have a really big extended family. Just on Eid day we can have sixty people. I wear proper hijab for those occasions. On these days when all the cousins come together we have problems because my family has not adopted a culture of segregation and we have a very mixed get-together. But when my cousins are there I have to cover myself. (Nasha, Pakistani woman in her mid-twenties)

There is leeway for negotiation of community arrangements, as there are tensions between some aspects of Scottish social culture and some South Asian and Islamic mores and principles. Notably, Muslims lament that drinking is one of the main barriers to integration in Scottish social life (Homes et al. 2010). A powerful tool of socialisation, bonding, and networking, drinking plays a more important social role than one may think. In fact, about one in five Scottish people (20 per cent) finds it strange if someone refuses an alcoholic drink, and considers getting drunk to be a perfectly acceptable thing to do during the weekend. These figures go up to over 30 per cent (refusing a drink) and to 40 per cent (getting drunk) among those aged 18-29 (Sharp et al. 2014). Deciding not to partake in social events in which alcohol is involved can backfire on educational and career prospects, as drinks receptions and dinners are typical spaces where job and personal connections can be nurtured. This may particularly affect those Muslims who are climbing the professional ladder rather than those who are already at the top:

Deciding not to drink is clearly more difficult for some people. For example, professionally, for meetings I will not choose to have them in a pub. That said, when we do have dinner, a professional dinner or whatever, it is part of British culture that people are used to partaking in that [drinking] and I do not. It is fine. I think that is their choice. I think that where it is more difficult is if you are not part of that process, if you do not progress up that social ladder or professional ladder. So for me it does not really arise as an issue. But I understand that for others this can be an issue because this is where decisions and key discussions take place and it can compromise people. (Ali, British Pakistani man in his mid-forties)

Rigid or fluid mechanisms of cultural openness often depend on the influences and expectations of one's extended family and closest community, be they friends, mosque members, or others. In the case of Nasha and other Muslims, family influences and her own understanding of Muslimness and adherence to cultural community expectations allow the negotiation of her own self-presentation, 
such as wearing a hijab or not, in front of members of her family. The same family and community influences and understandings of Muslimness enforce strict moral and social norms in ruling out contested Western practices, such as drinking, that clash with traditional conceptions of a Muslim life.

Choosing not to drink and, extensively, not to attend social spaces that revolve around a drinking culture, such as nightclubs, is not easy. For many Muslims, it means adopting a policy of self-exclusion from a key sphere of socialisation. Nevertheless, there are growing feelings, particularly among the younger Scottish-born cohort, that nurturing a healthy detachment from the most problematic tools of socialisation can be achieved through appropriate social skills:

Drinking is the biggest thing. Also, Muslims try not to go to nightclubs. Those who go do so because they are not educated about their religion or do not practise enough but, apart from that, social mixing and relationships outside marriage are probably the most problematic aspects. These are the areas that are probably the hardest to deal with for young people. It does not matter whether one is a Muslim or not, they are all the same-young people who want to enjoy life! Enjoy those things that you can, and the kind of things that you cannot, you can still go out together but you do not have to go to a club. You go to a restaurant, have food, go to a cinema, watch a movie, these kind of things that people can do while respecting each other. (Nasir, Scottish Pakistani man in his early thirties)

There is a rather orthodox undertone in the words of Nasir, a local imam, that several young Scottish Muslims do not necessarily agree with, although the view that certain elements of Scottish and Western culture cannot be incorporated within the normative boundaries of the Muslim community is shared by some younger and many older Muslims. A performed display of 'moral' Muslimness-avoiding drinking, clubbing, male/female physical contact, and so on - certainly defines a number of Muslims' public attitudes. Broadly speaking, it ties in with wider research that found British Muslims to be more socially conservative than both non-Muslim Britons (Lewis and Kashyap 2013) and French and German Muslims (Gallup 2009). Whether this hampers a process of cultural cross-fertilisation and exchange with the Scottish community remains to be established. Certainly, drinking is a very sensitive issue and, possibly, a lose-lose situation. If Muslims decide to drink, they will be stigmatised by fellow Muslims; if they decide not to drink, they will be stigmatised by broader society (Fletcher and Spracklen 2013). Arguably, fixed stances on both sides do not ease tensions. While one may chastise young Muslims for not 'trying' to be less Muslim and enjoying a pint at the pub, one may also reprimand young Scottish people for not 'trying' to be less Scottish and sipping an orange juice on a Saturday night. The key point here is that some social barriers might be slow to break, and it might take generations until being Scottish is as coterminous with being Muslim as it is with being Christian or being atheist or being all or none of them at the same time.

Leisure activities in a broader sense impact on Muslims' sensitivities and demonstrate the changing face of the Muslim community living in Scotland. With many older generations baffled at the idea of their younger members dating 'like Westerners', a disgruntled Mustafa, an old Pakistani man, expressed all his disappointment when the author (a white non-Muslim man) told him that Muslim women had agreed to participate in his research. Mustafa's views, as bizarre as they may seem, are not too uncommon among the older cohort of Muslims. In fact, they represent 'traditional views of purdah-a need to "curtain" women away from non-related Muslims, especially in a Western society routinely dismissed as Godless, and marked by drunkenness, sexual promiscuity, and lack of respect for elders' (Lewis 2007, pp. 27-28). From this perspective, one may understand the dilemma that young Muslims face when approaching the members of the opposite gender they come into contact with, who are rarely non-Muslim:

Leisure activities are a big issue for Muslims in Scotland. Let's say that you have a nine-to-five job. What do you do outside your job? You go for a beer with your mates? No, you cannot do that, so at the workplace there are closer bonds among those who have gone to the pub after work. [ ... ] Leisure in England is a lot more optimistic. Even the dating scene ... here 
it is really hard to date someone. Okay, dating is forbidden in Islam! [Laughs.] Okay, let's just say meeting members of the opposite gender. It is impossible to do it in Scotland. (Arif, Canadian Bangladeshi man in his early thirties)

These are just a few of the problems that Scottish Muslims face in their day-to-day socialisation. These constitute pragmatic considerations on how to go about one's life as a minority within a non-Muslim-majority Scotland. But they also raise a more general question of post-migration integration, which is only going to be briefly introduced here. Such a question asks how society should deal with cultural diversity in racially and ethnically mixed polities (Meer 2014). Still a contentious topic, integration usually refers to two notions: one-way assimilation and two-way adaptation (Castles et al. 2002). Assimilation is essentially a one-way process of integration into the majority society, which requires minority groups to adopt the dominant values, beliefs, and norms. Here, society remains impermeable to, and instead seeks to homogenise, the cultural diversity of minorities. Such a process presupposes that failure to assimilate should not be a reason to complain over exclusion and discrimination (Parekh 2000). A system of integration typical of French and Italian societies, this is far from both the ideals and the realities of minorities living in Scotland.

Scotland follows a 'two-speed' integration process. Some aspects of day-to-day social life take a 'partial assimilation' orientation - that is, a less intense form of the assimilationist approach, which limits its scope to public life. Partial assimilation expects minorities to blend into the dominant political culture but allows them to retain cultural diversity within their families and in parts of civil society (Meer 2014). This is evidenced by ongoing tensions between visible aspects of Muslimness and more orthodox Western norms, which pop in and out of existence depending on the circumstances. Wearing a hijab, looking 'foreign', and practising Islam are met with suspicion, if not outright discrimination, on the street, at work, in schools, and in other spaces by a small section of the Scottish community. The socialisation problems covered earlier demonstrate that Scotland is yet to achieve mutual integration, as non-Muslims do not want to give up their traditional social life to the same extent that a number of Muslims have given up their traditional values to join a more 'Westernised' way of life. Arif touches upon the possibilities for intercultural integration yet highlights the problems that still persist in building social bridges between different communities in Scotland:

I think that the drinking culture separates people. My cousin here married a white Scottish person. However, he does not drink, his family does not drink-they had something in common. (Arif, Canadian Bangladeshi man in his early thirties)

Partial assimilation is normally associated with integration policies aimed at promoting social cohesion and fostering a national identity and value system, a common language, ceremonies of naturalisation and other public displays of sociocultural homogeneity and unity (Kostakopoulou 2010). While the Scottish nationalist impetus is strong, it does not aim to impose its own features on minorities. Moreover, its political aspirations are inclusive rather than exclusive. This has historically characterised a careful Scottish nationalist approach of 'cultivat[ing] a sense of Scottish identity that [ ... is] not based on any narrow or exclusivist definition' (McConaghy 2015, p. 11). Therefore, Scotland confines partial assimilation to some aspects of social life, such as socialisation, leisure, and so on, that are in the process of being transformed through a slow, generational adaptation to the globalisation of cultures. This connects to European scholarship (Roy 2004) that illustrates that Islam in the West has the capacity to malleably adapt to Western frameworks and has gone through the 'Westernisation' of some of its values' expression. The Islamic adaptation to the Western concept of the nuclear family, as opposed to the traditional Islamic polygamous extended family, is a notable example.

The ideals and the political aspirations of Scotland match with a limited or half-baked two-way process of adaptation, which conceives of its social and cultural landscapes as porous and open to the diversity of values, beliefs, and lifestyles and values integration for its potential to fulfil equal opportunities (Brighton 2007). Scotland has so far limited its two-way process of adaptation to the least contested areas of social life, which range from the promotion of Islam at public events, through 
geographical non-segregation, to general openness to Muslims' diversity. It is yet to be established how Scotland would react if its Muslim community, feeling empowered within a nation that promotes its 'many cultures', demanded Muslim faith schools or shari'a councils. Given Scotland's increasingly non-religious and secular connotations (National Records of Scotland 2013), the romantic idea of infinite friendliness and total inclusiveness would likely start to crumble. There are of course a number of spheres in which integration is measured and it is not the aim of this paper to touch upon all of them. It will suffice to say that, while the focus here is predominantly on social connections, access to housing, employment, education, and health are also crucial, as are so-called 'facilitators', such as language and cultural knowledge, and safety and stability (Ager and Strang 2008).

\section{Muslim Belonging to ‘Big Tent' Scotland}

To further understand the contours and the meanings of people's belonging to Scotland, one must draw on the historical, social, cultural, and political dimensions of the country. Along with historian Tom Devine, the most authoritative voice in this respect is McCrone (2001), whose book Understanding Scotland: The Sociology of a Nation represents a sociological masterpiece on the formation of Scotland and Scottish national identity. After having played a major role in the emergence of the Enlightenment throughout the eighteenth century (Herman 2003), ${ }^{11}$ Scotland has undergone recent developments, which McCrone breaks down into three main historical periods:

1. The 1900s, when Scotland was a very modern and industrial country driven by an imperialist politics, had an ethically and religiously Protestant outlook and was dominated by local capital.

2. The 1950s, when the previous locally based system of power lost ground to a central state power and patriotism took off, mainly through the symbolic role that World War I and World War II played in shaping a strong British identity.

3. The 2000s, in which the centrality of the family had been eroded in favour of strong individualism, the Scottish economy opened up to world markets, and access to higher education expanded to allow social mobility, although unequal distribution of social opportunities meant that class and gender barriers impeded equitable access to top jobs.

Nowadays, Scotland 'has a degree of statehood (a devolved parliament [established through the Scotland Act 1998], a governing bureaucracy), but it is still best described as a stateless nation, an imagined community, with considerable institutional autonomy and, at least as yet, no sovereign parliament' (McCrone 2001, p. 6). McCrone maintains that Scotland has built up a strong national identity since the 1960s, following the discovery of the North Sea oil and the rise in the Scottish National Party's popularity. While being a rather elusive term, the concept of nation in McCrone takes both the shape of a moral conscience based on collective solidarity and an imagined common history (Renan 1939) and the connotation of a socially constructed community characterised by a vertical (time) and horizontal (space) sense of belonging (Anderson 1996. )Moreover, McCrone adds, nationalism brings together a variety of elements that are sociological, political, and psychological in nature. The historical continuity of Scotland, as a mutable yet enduring national artifact, is captured by McCrone (2001, p. 49) when he argues that

There can be little doubt of the ideological power of 'Scotland' as a nation in these terms. It implies that Scotland is not simply a collection of rocks, earth, and water, but a transcendent idea which runs through history, reinterpreting that history to fit the concerns of each present.

Elsewhere also considered a political ideology (Kyriakides et al. 2009,) nationalism in McCrone's work emerges as a powerful force that mobilises culture to achieve goals such as avenging previous

11 The Scottish opposition to slavery during the Enlightenment is particularly interesting and was shared by David Hume, Robert Wallace, and James Steuart (Webster 2003). 
exploitation and discrimination, offering a voice in the political sphere and meeting social needs for a shared, individual, and collective identity. Built upon strong anti-racist connotations and grounded in the idea of an 'oppressed Scottish identity' (possibly perpetuating the alleged inferiorisation of Scottish people (Cusick 1994), post-war Scottishness has contrasted with English nationalism, which is thought to be based on oppressive imperialism (Kyriakides et al. 2009). The core of Scottish nationalism is "firmly embedded in a "sense of place" rather than a "sense of tribe" [ ... which] derives from medieval realpolitik rather than moral superiority on the part of the Scots' (McCrone 2001, p. 155, emphasis in the original).

In the Scottish Muslim community, such a sense of place is played out in two ways. On the one hand, it serves the purpose of expressing a clear cultural and ideological demarcation between the boundaries of Scottishness and Englishness. A sense of belonging to Scotland and a feeling of being Scottish relative to one's non-belonging to England is part and parcel of the experiences of many of those Muslims who openly declare their emotional and cultural allegiance to the country, at times even in the absence of direct experience of life in England. Other research demonstrates that Scottish Muslims identify more with Scotland than Great Britain (Hopkins 2007a) and have stronger national sentiments towards Scotland than English Muslims have towards England (Kidd and Jamieson 2011). On the other hand, Muslims' feelings of Scottishness are also played out in absolute terms through declarations of proud belonging to Scotland per se. Scotland is perceived to be a place where freedom of expression is valued, multiculturalism is promoted (for example, through the social enactment of the 'One Scotland' political manifesto), and ethnicity, while not unimportant, is not necessarily an ultimate barrier to inclusion. This is captured by McCrone and Bechhofer (2010), who argue that Scotland offers a low entry tariff to national claims of Scottishness, and is partly restated by Meer (2015) in a study locating Scottish political elites' aspirational pluralism within a context that steers away from ethnically fixed barriers to one's belonging to Scotland. Muslims' active engagement with the notion of Scotland and their claims of belonging through markers of Scottish identity help sustain ideas of nation as an intersubjective reality, which exists in collective imaginations yet plays a powerful role in binding people together (Harari 2014).

Many Muslims share the narrative, whether real or perceived, of Scotland as a relatively open and porous sociocultural space, which possesses almost spiritual capacities to absorb and integrate human elements and products of diversity. A measure of Scottish egalitarianism can be found in the study of Hussain and Miller (2006). The study consists of a large-scale survey of both Pakistani and English minorities living in Scotland and the majority populations living in both Scotland and England and compares perceptions of discriminatory attitudes in Scotland and England. Despite the fact that Scottish people score higher on Islamophobia than Anglophobia in relative terms, only 42 per cent of Scottish people consider conflicts between Muslims and non-Muslims to be at least fairly serious, as opposed to 61 per cent of English people living in England. More broadly, Scotland is perceived to be less Islamophobic than England. Among the explanations proposed by Hussain and Miller are factors related to the particular settlement and development of Muslim communities in Scotland and the specific features of Scottish geographies and sociopolitical attitudes towards diversity:

- the smaller Muslim population in Scotland;

- the fact that many Muslims in Scotland are self-employed and work in business, while a good number of Muslims in England are unskilled labourers;

- higher levels of segregation within English Muslim communities;

- higher levels of racism in England, possibly due to the fact that Islamophobia is 'much more closely tied to English nationalism within England than Scottish nationalism within Scotland' (Hussain and Miller 2006, p. 65).

Other research (Homes et al. 2010) has also found that the process of integrating Muslims into society is easier in Scotland than England due to lower fears of terrorism, lower settlement numbers, and certain positive features of Scotland, such as friendliness, sociability, and a welcoming disposition. 
This furthers the political idea of Scotland as 'an inclusive club with a low entry tariff $[\ldots$ and characterised by a] "big tent" Scottishness, such that everyone living in the country has a claim' (McCrone and Bechhofer 2010, p. 926). Moreover, it builds upon the notion of the Scottish egalitarian society, which works as a social ethos and 'a celebration of sacred beliefs about what it is to be Scottish [ $\ldots$ and functions as] an ideological device for marking off the Scots from the English' (McCrone 2001, pp. 102-3). On the ground, this translates into Muslims' generally positive social and cultural experiences (see Colourful Heritage 2016), in a context in which discrimination exists but is not a specific function of Scotland per se. Instead, it perpetuates a post-9/11 national and global perceived stigmatisation of Muslimness (Bonino 2012, 2013) within the Scottish context. However, while it is probably true that, for various reasons, Scotland offers a more open sociocultural environment, the myth of Scottish egalitarianism rests on a more nuanced reality. There is some truth in the romantic notions of Scots' friendliness towards Scotland's Indian subjects (Maan 1992). Similarly, in the context of a Scottish nationalism deemed to be a progressive historical force, 'the [British] Empire was consequently represented either as the triumphant moment of British nationalism, or as a historical impediment to the ultimate triumph of Scottish nationalism' (Condor and Abell 2006, pp. 469-70). But it would be historically amnesiac to forget that the Scots were deeply involved in all the aspects of the British Raj (Devine 2012), possibly through a larger contribution than that of England, and were proud of what 'they and their kinsfolk had accomplished' (Glass 2014, p. 147). Yet, a lack of historical memory seems to affect many young Muslims who still attach themselves to the Scottish narrative of tolerance. This narrative, their strong Scottish identities, and their generally positive lived experienced of Scottish life are making it a Scottish experience to be Muslim.

\section{A Scottish Experience to be Muslim}

It has been highlighted that the sociocultural context that many Scottish Muslims inhabit differs in many ways from their parents' experience of Scotland. Whether they were born and raised in Scotland, whether they moved to Scotland at an early age and were partially socialised within Scottish culture, or whether they spent their childhood and early adulthood in their home countries and then migrated to Scotland, the traditional, ethno-cultural migrant sense of community is giving way to a cross-bred Scottish Muslim community. Ali posits that Muslims in Scotland are going through a historical process of ethnic identity dilution. Instead, they embrace both national/civic Scottish and religious Muslim experiences, the latter at times being underpinned by ideological and political connotations:

Historically here, being a Muslim has always been synonymous with being Pakistani or Bangladeshi. That is a historical perspective and if you look at it now, it is no longer true. In time, people of South Asian origin will be the minority. It will be predominantly a British experience to be a Muslim in the UK context. It has already begun to happen. It will be like in the United States, where it is predominantly an Afro-American experience. English will reduce some of the barriers to entering into Islam. (Ali, British Pakistani man in his mid-forties)

As for the epitome of the current endurance of ethno-cultural modalities of Muslimness, especially within the older generations, some Muslims pick language as the main 'culprit'. The command of a lingua franca not only allows basic communication but also facilitates participation in civil society. Furthermore, it buys Muslims into the project of Scottishness that may not be normatively built upon language, but pragmatically rests upon cross-ethnic tools of unity. As many believe, it is becoming more and more of a Scottish experience to be Muslim:

One benefit of being Muslim here is that you can come from any corner and mix up. Only sometimes, language barriers are a problem to interaction. There are Arabs and I am from Pakistan. There are people from India, Bangladesh, Iran, Indonesia, Malaysia, and so on. So you need a lingua franca. English is the language that fills the gap. [ . . ] If people know 
English, then there is no problem. Otherwise, people need to acquire different languages for different interactions.

(Sarmad, Pakistani man in his early fifties)

There are definitely micro-communities but one of the things to remember is that these issues will fade with the next generations. Take for example Urdu-speaking mosques. Whoever is not Urdu-speaking, even a Pakistani who is not Urdu-speaking-for example, my kids-is completely out of place in that context. But it is a matter of time because that is not going to persist when new generations will not speak Urdu anymore. (Ali, British Pakistani man in his mid-forties)

The transition from an ethno-cultural to a national and religious community is certainly a natural generational and environmental evolution that touches upon ideas of migration, settlement, and development. It is also an environmental adaptation to maximise group survival. The advantages of sharing a common language in order to take an active part in Scottish cultural and political life are obvious. Similarly, upholding two of the main 'markers of Scottish identity' (Kiely et al. 2001)-that is, place of birth and education - facilitates claims of Scottish identity and recognition from wider society.

What might go unnoticed are the benefits of actively engaging with the ideas, even if not the practices, whatever these might be, of the Scottish nation in ways that allow some detachment from ethno-culturalist understandings of nationhood towards the partial embracing of civic nationalism in the form of 'allegiance to a particular social system and constitution' (Weber n.d., p. 5). This is particularly visible in declarations of allegiance to Scotland as opposed to England, ${ }^{12}$ the elevation of Edinburgh to status of 'promised land' and the overall identification with the Scottish narrative of relative openness and tolerance. Declared belonging and active engagement with Scottish nationalism functions as a solution to the problem of competitive exclusion posed by Gause's law (Gause 1934), which posits that when 'two populations are complete competitors and one is dominant over the entire niche, the less efficient competitor will be eliminated from the arena of competition' (Abruzzi 1993, p. 56). By avoiding competition with the definition of the main framework of Scottishness, which is premised upon an inclusive and civic, rather than exclusive and ethnic, identity (McConaghy 2015), and by underplaying ethnicity and culture in identity and community claims, Scottish Muslims achieve two results.

First, they retain an ecologically equal position within Scottish society by avoiding challenging the terms of reference of a Scottish civic nationalism. These terms are, at least in the public imagination (Leith and Soule 2012), based on an inclusive identity, and thus do not threaten Muslims' multiple identities as the ethnically fixed (Fenton and Mann 2011) and closed character of Englishness would. Muslims attach themselves to an aspirational, inclusive sense of civil nationalism. At the same time, they manage to retain ethno-cultural elements, such as family traditions, clothing, food, and music, as side features of their identities. Second, they shape a cross-ethnic, religiously cohesive notion of Muslim community, an ecology in which both Muslimness and Scottishness can coexist. This also solves the English multicultural 'problem', which emerges from an ethnically fixed idea of Britishness that feels threatened by a myriad of ethnic and cultural claims that are considered to be too distinct to be reconciled. Building on very wide and strongly inclusive social categories of group identity ('Scottish' and 'Muslim') that contain, restrain, and dilute ethnic differences, a rather vague yet malleable and marketable concept of unity takes centre stage and plays upon the combined strengths that Scottishness and Muslimness can offer to Muslims' claims of belonging. In the end, Muslims maximise individual and group survival by giving up some of their ethno-cultural distinctiveness, taking up the Scottish national narrative and building a cross-ethnic Muslim collectivity. In other words, Muslims maintain

12 According to Weber (n.d.), Scotland's civic attitude in contrast to England's demonstrates that civic nationalism, and not only ethnic nationalism, can also be exclusive. 
differences at the individual level but dilute them at the group level to the benefit of both. The interplay of Scottishness and Muslimness is nowhere better symbolised than in the creation of a halal haggis, by a butcher in Edinburgh (The Scotsman 2003), and the Islamic tartan, blue for the Saltire and green for Islam, by Scottish Muslim entrepreneur Azeem Ibrahim (Marshall 2012).

The 'new Muslims' do not belong to the community structures of 'Mosque B', in which 'society and Islamic "community" are coterminous' (Lewis 2007, p. 9) insofar as individuals claim belonging to the ethnic community and maintain relationships with God at the same time. Instead, they fit

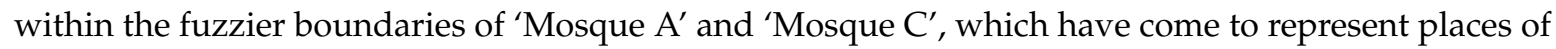
worship, education, and socialisation all at the same time. 'Mosque $\mathrm{A}^{\prime}$ brings together Muslims from very diverse backgrounds, whether Pakistanis, Somalis, or Tunisians, whether young or old, whether migrant or Scottish-born, and promotes sentiments of sharedness based on group commitment to the same set of beliefs, morals, and practices. It is a Muslim community that is grounded on broad religious homogeneity, though infused with Saudi theological influences, relative cultural similarity, and variable ethnic diversity. In Roy (2004) terms, 'Mosque A' represents a 'parochial level' form of community-that is, a faith institution that employs religion as a symbol of unity and common identity, which is usually formed around mosques, spiritual congregations, and student associations.

'Mosque C' targets predominantly Scottish-born Muslims with a view to furnishing them with Scottish sociocultural tools of survival. It tackles the perceived inadequateness of religious personnel (imams and ulama), who are normally brought from home countries, have little contextual knowledge of British and Scottish issues (Lewis 2007), and deliver sermons in their own native language (often Urdu; see Maan 2014), by training Scottish and British-born imams. It holds prayers in English and organises open days and interfaith events for non-Muslims. Furthermore, the experiences of its attendees are deeply embedded in Scottish life:

Young Muslims do not really care about cultural views. They are here living the culture of Scotland as long as it is still compatible with their religion. That is what they want. They do not want it to be compatible with Pakistani culture, because Pakistani culture is not their culture. They do not call themselves Pakistani. They do not sign the ethnicity form saying 'Pakistani'. They want to be Scottish, but they want to be Muslim too. Scottish Muslims: that is what they want to be. (Nasir, Scottish Pakistani man in his early thirties)

This mosque actively encourages intercommunity contact and takes a proactive role in training local religious personnel who can speak English and can be attuned to the needs of Scottish Muslims. This is a direction supported and encouraged by the Muslim Council of Scotland (MCS) (Herald Scotland 2015), an organisation representing Muslim associations, mosques, and institutions across the country. It is also a direction that has been partly taken by Glasgow Central Mosque, a place of worship that features large panels of glass typical of Glaswegian public buildings and that hosts Muslims who marry in kilts to the sound of bagpipes (The Economist 2015). It is true that the Muslim community and Scottish mosques are often ethnically fragmented and theologically divided (Archambault 2007), to the point that different mosques have different timetables for Ramadan and different days for the celebration of Eid (Maan 2014). Glasgow Central Mosque has also been at the centre of serious cultural tensions between orthodox and liberal Muslims mixed with issues of governance and institutional development. Ethno-cultural and theological factionalisms are part and parcel not only of mosques in Glasgow and Edinburgh, but also of places of worship in other Scottish cities, for example Dundee (Caraballo-Resto 2010). However, intercommunity contact remains crucial for informing Muslims' and non-Muslims' reciprocal views, since familiarity with minority groups helps reduce levels of prejudice (Field 2007, p. 465). As a Muslim woman, Nasha, puts it, the goal of Scottish Muslims should not be to intensify the 'Muslim factor' in their day-to-day way of 'doing community'. Instead, the possibly utopian goal should be to leave aside 'the Islamic factor', 'the Christian factor', 'the Jewish factor', and 'the atheist factor' to make Scotland feel much more like a super-community that values, yet transcends, diversity. 


\section{Conclusions}

The reshaping of Muslim community boundaries as a result of increased individual affiliation to Islam and a strong sense of belonging to Scotland is well underway and is changing old concepts of Muslims as mere migrants with strong ethnic identities and an evergreen nostalgia for their countries of origin. The traditional ethno-cultural, predominantly South Asian, Muslim community bound by kinship, honour, and tribal affiliation has given way to a more ethnically transversal aggregate of globally loosely affiliated and locally physically connected people. These people find a common ground in their belonging to Islam and in an externally scrutinised yet proudly internalised sense of Muslimness. The Scottish ethos of tolerance; peaceful, democratic, and civic nationalism (McConaghy 2015); vivid and popular cultural iconographies exemplified by the poetry of Robert Burns and by traditional bagpipe music (The Economist 2009); low entry tariff; a sense of oppressed identity; and active detachment from a perceived 'imperialist' England have shaped emotions of belonging and unity among young Muslims. These young people channel their proud Scottish identities into an ongoing Scottish sense of being Muslim that, while not free from cultural tensions, contains the seeds of success. Young Scottish Muslims have survived the post-9/11 stage of perceived global stigmatisation. Locally, they have both formed ties within their own changing community and built bridges with the non-Muslim majority. It is in the hands of these new generations of Muslims, with their ability to both retain some of their parents' tools of community cohesion and, at the same time, develop a sense of collective identity more attuned to Scottish society and the contemporary world, that the future of the Scottish Muslim community rests. There is little doubt that the intermingling of Scottishness and Muslimness in the construction of a cross-bred Scottish Muslim community will eventually contribute to building a new Scottish society. But it would be inaccurate and misleading to depict the future and, in particular, the present through rose-tinted glasses and to gloss over the discrimination that Muslims have historically faced and continue to face. It is important that the lingering presence of a post-9/11 securitisation of Muslimness and forms of everyday discrimination are not overshadowed by romantic narratives of Scotland as a land of tolerance.

Funding: This research received no external funding.

Acknowledgments: The author would like to thank Edinburgh University Press for permission to reproduce Chapter 4 of Muslims in Scotland: The Making of Community in a Post-9/11 World (Bonino 2017) for which they hold copyright.

Conflicts of Interest: The author declares no conflict of interest.

\section{References}

Abbas, Tahir. 2013. "Last of the Dinosaurs": Citizen Khan as Institutionalisation of Pakistani Stereotypes in British Television Comedy. South Asian Popular Culture 11: 85-90. [CrossRef]

Abruzzi, William. 1993. Dam That River! Ecology and Mormon Settlement in the Little Colorado River Basin. Lanham: University Press of America.

Adewunmi, Bim. 2012. Citizen Khan: An Asian Sitcom Star is Born. The Guardian, August 22. Available online: http:/ / www.theguardian.com/tv-and-radio/2012/aug/22/citizen-khan-sitcom-star-born (accessed on 24 January 2019).

Ager, Alastair, and Alison Strang. 2008. Understanding Integration: A Conceptual Framework. Journal of Refugee Studies 21: 166-91. [CrossRef]

Amin, Ash. 2002. Ethnicity and the Multicultural City: Living with Diversity. Environment and Planning A 34 : 959-80. [CrossRef]

Anderson, Benedict. 1996. Imagined Communities: Reflections on the Origin and Spread of Nationalism. London: Verso. First published 1983.

Ansari, Humayun. 2004. The Infidel Within: Muslims in Britain Since 1800. London: Hurst.

Archambault, Hannah. 2007. A Community United? Going in Search of Community with Edinburgh Muslims. Edinburgh Papers in South Asian Studies 23: 1-35. 
BBC News. 2012. Sitcom Citizen Khan Prompts 185 Complaints to the BBC. BBC News, August 29. Available online: http:/ / www.bbc.co.uk/news/entertainment-arts-19395994 (accessed on 24 January 2019).

BBC2. 1966. Minorities in Britain. Available online: http://thespace.org/items/e00008jc?t=ywfx (accessed on 20 March 2014).

Bolognani, Marta. 2007. The Myth of Return: Dismissal, Survival or Revival? A Bradford Example of Transnationalism as a Political Instrument. Journal of Ethnic and Migration Studies 33: 59-76. [CrossRef]

Bolognani, Marta. 2009. Crime and Muslim Britain: Race, Culture and the Politics of Criminology Among British Pakistanis. London: Tauris Academic Studies.

Bonino, Stefano. 2012. Policing Strategies against Islamic Terrorism in the UK after 9/11: The Socio-Political Realities for British Muslims. Journal of Muslim Minority Affairs 32: 5-31. [CrossRef]

Bonino, Stefano. 2013. Prevent-ing Muslimness in Britain: The Normalisation of Exceptional Measures to Combat Terrorism. Journal of Muslim Minority Affairs 33: 385-400. [CrossRef]

Bonino, Stefano. 2016. Policing Forced Marriages Among Pakistanis in the UK. In Human Trafficking: The Complexities of Exploitation. Edited by Margaret Malloch and Paul Rigby. Edinburgh: Edinburgh University Press, pp. 159-74.

Bonino, Stefano. 2017. Muslims in Scotland: The Making of Community in a Post-9/11 World. Edinburgh: Edinburgh University Press.

Brighton, Shane. 2007. British Muslims, Multiculturalism and UK Foreign Policy: "Integration" and "Cohesion" in and Beyond the State. International Affairs 83: 1-17. [CrossRef]

Caraballo-Resto, Juan. 2010. Contentions in the Making: Discussing Secularism Among Scottish Muslims. In Muslim Societies and the Challenge of Secularization: An Interdisciplinary Approach. Edited by Gabriele Marranci. Dordrecht: Springer, pp. 151-64.

Carroll, Lucy. 1998. Dossier 20: Arranged Marriages: Law, Custom and the Muslim Girl in the UK. London: Women Living Under Muslim Laws.

Castles, Stephen, Maja Korac, Ellie Vasta, and Steven Vertovec. 2002. Integration: Mapping the Field. London: Home Office.

Colourful Heritage. 2016. Colourful Heritage Project: Capturing the Memories, Stories and Adventures of the First Generation. Available online: http:/ / www.colourfulheritage.com (accessed on 24 January 2019).

Condor, Susan, and Jackie Abell. 2006. Romantic Scotland, Tragic England, Ambiguous Britain: Constructions of "the Empire" in Post-Devolution National Accounting. Nations and Nationalism 12: 453-72. [CrossRef]

Cusick, Linda. 1994. Scottish Inferiority. Scottish Affairs 9: 143-50. [CrossRef]

Deakins, David, Mohammed Ishaq, and David Smallbone. 2005. Minority Ethnic Enterprise in Scotland: A National Scoping Study. Edinburgh: Scottish Executive.

Devine, Tom. 2012. The Scottish Nation: A Modern History. London: Penguin Books.

Edmunds, June. 2010. “Elite” Young Muslims in Britain: From Transnational to Global Politics. Contemporary Islam: Dynamics of Muslim Life 4: 215-38. [CrossRef]

Fenton, Steve, and Robin Mann. 2011. “Our Own People": Ethnic Majority Orientations to Nation and Country. In Global Migration, Ethnicity and Britishness. Edited by Tariq Modood and John Salt. Basingstoke: Palgrave Macmillan, pp. 225-47.

Field, Clive. 2007. Islamophobia in Contemporary Britain: The Evidence of the Opinion Polls, 1988-2006. Islam and Christian-Muslim Relations 18: 447-77. [CrossRef]

Fletcher, Thomas, and Karl Spracklen. 2013. Cricket, Drinking and Exclusion of British Muslims? Ethnic and Racial Studies 37: 1310-27. [CrossRef]

Forced Marriage Unit. 2015. Statistics January to December 2014. London: Home Office and Foreign and Commonwealth Office.

Gallup. 2009. The Gallup Coexist Index 2009: A Global Study of Interfaith Relations. New York and London: Gallup and The Coexist Foundation.

Gause, Georgii. 1934. The Struggle for Existence. Baltimore: Williams and Wilkins.

Glass, Bryan. 2014. The Scottish Nation at the Empire's End. Basingstoke: Palgrave Macmillan.

Harari, Yuval Noah. 2014. Sapiens: A Brief History of Humankind. London: Harvill Secker.

Hellyer, Hisham. 2007. Engagement with the Muslim Community and Counter-Terrorism: British Lessons for the West. Analysis Paper 11. Washington, DC: Brookings Institution. 
Herald Scotland. 2015. How Scotland's Muslims are Fighting the Rise of Radical Islam at Home. Herald Scotland, February 1. Available online: http://m.heraldscotland.com/news/13199694.Revealed_how_Scotland_s_ Muslims_are_fighting_the_rise_of_radical_Islam_at_home (accessed on 24 January 2019).

Herman, Arthur. 2003. The Scottish Enlightenment: The Scots' Invention of the Modern World. London: Fourth Estate. Higher Education Funding Council for England. 2010. Trends in Young Participation in Higher Education: Core Results for England. Available online: http:/ / www.hefce.ac.uk/media/hefce/content/pubs/2010/201003/ 10_03.pdf (accessed on 24 January 2019).

Homes, Amy, Chris McLean, and Lorraine Murray. 2010. Muslim Integration in Scotland. Edinburgh: Ipsos MORI Scotland.

Hopkins, Peter. 2007a. "Blue Squares", "Proper" Muslims and Transnational Networks: Narratives of National and Religious Identities Amongst Young Muslim Men Living in Scotland. Ethnicities 7: 61-81. [CrossRef]

Hopkins, Peter. 2007b. Global Events, National Politics, Local Lives: Young Muslim Men in Scotland. Environment and Planning A 39: 1119-33. [CrossRef]

Hopkins, Peter. 2009. Responding to the "Crisis of Masculinity": The Perspectives of Young Muslim Men from Glasgow and Edinburgh, Scotland. Gender, Place and Culture 16: 299-312. [CrossRef]

Huq, Rupa. 2013. Situating Citizen Khan: Shifting Representations of Asians Onscreen and the Outrage Industry in the Social Media Age. South Asian Popular Culture 11: 77-83. [CrossRef]

Hussain, Yasmin, and Paul Bagguley. 2012. Securitized Citizens: Islamophobia, Racism and the 7/7 London Bombings. The Sociological Review 60: 716-34. [CrossRef]

Hussain, Asifa, and William Miller. 2006. Multicultural Nationalism: Islamophobia, Anglophobia, and Devolution. Oxford: Oxford University Press.

Kabir, Nahid. 2010. Young British Muslims: Identity, Culture, Politics and the Media. Edinburgh: Edinburgh University Press.

Kidd, Sara, and Lynn Jamieson. 2011. Experiences of Muslims Living in Scotland. Edinburgh: Scottish Executive.

Kiely, Richard, Frank Bechhofer, Robert Stewart, and David McCrone. 2001. The Markers and Rules of Scottish National Identity. Sociological Review 49: 33-55. [CrossRef]

Kostakopoulou, Dora. 2010. Matters of Control: Integration Tests, Naturalisation Reform and Probationary Citizenship in the United Kingdom. Journal of Ethnic and Migration Studies 36: 829-46. [CrossRef]

Kundnani, Arun. 2014. The Muslims are Coming! Islamophobia, Extremism, and the Domestic War on Terror. London: Verso Books.

Kyriakides, Christopher, Satnam Virdee, and Tariq Modood. 2009. Racism, Muslims and the National Imagination. Journal of Ethnic and Migration Studies 35: 289-308. [CrossRef]

Laliótou, Ioanna. 2004. Transatlantic Subjects: Acts of Migration and Cultures of Transnationalism between Greece and America. Chicago: University of Chicago.

Leith, Murray, and Daniel Soule. 2012. Political Discourse and National Identity in Scotland. Edinburgh: Edinburgh University Press.

Lewis, Philip. 2007. Young, British and Muslim. London: Continuum.

Lewis, Valerie, and Ridhi Kashyap. 2013. Are Muslims a Distinctive Minority? An Empirical Analysis of Religiosity, Social Attitudes, and Islam. Journal for the Scientific Study of Religion 52: 617-26. [CrossRef]

Maan, Bashir. 1992. The New Scots: The Story of Asians in Scotland. Edinburgh: John Donald Publishers.

Maan, Bashir. 2014. Muslims in Scotland. Glendaruel: Argyll Publishing.

Macey, Marie. 1999. Class, Gender and Religious Influences on Changing Patterns of Pakistani Muslim Male Violence in Bradford. Ethnic and Racial Studies 22: 845-66. [CrossRef]

Marshall, Chris. 2012. 'Pattern's Principles. The Scotsman, July 8. Available online: http:/ /www.scotsman.com/ news/scotland/top-stories/revealed-pattern-s-principles-1-2399186 (accessed on 24 January 2019).

McConaghy, Kieran. 2015. Scotland and Separatism: Reverberations of the Scottish Independence Referendum on Separatist Politics. St Andrews: University of St Andrews, The Handa Centre for the Study of Terrorism and Political Violence.

McCrone, David. 2001. Understanding Scotland: The Sociology of a Nation, 2nd ed. London: Routledge.

McCrone, David, and Frank Bechhofer. 2010. Claiming National Identity. Ethnic and Racial Studies 33: 921-48. [CrossRef]

Meer, Nasar. 2014. Race and Ethnicity. London: Sage Publications. 
Meer, Nasar. 2015. Looking Up in Scotland? Multinationalism, Multiculturalism and Political Elites. Ethnic and Racial Studies 38: 1477-96. [CrossRef]

Modood, Tariq. 2004. Capitals, Ethnic Identity and Educational Qualifications. Cultural Trends 13: 87-105. [CrossRef]

Modood, Tariq. 2005. Multicultural Politics: Racism, Ethnicity and Muslims in Britain. Minneapolis: University of Minnesota Press.

National Records of Scotland. 2013. 2011 Census: Key Results on Population, Ethnicity, Identity, Language, Religion, Health, Housing and Accommodation in Scotland-Release 2A. Edinburgh: National Records of Scotland.

Parekh, Bhikhu. 2000. Rethinking Multiculturalism: Cultural Diversity and Political Theory. London: Macmillan.

Peace, Timothy. 2015a. European Social Movements and Muslim Activism: Another World but with Whom? Basingstoke: Palgrave Macmillan.

Peace, Timothy. 2015b. British Muslims and the Anti-War Movement. In Muslims and Political Participation in Britain. Edited by Timothy Peace. London: Routledge, pp. 124-37.

Peace, Timothy, ed. 2015c. Muslims and Political Participation in Britain. London: Routledge.

Qureshi, Karen. 2004. Respected and Respectable: The Centrality of "Performance" and "Audiences" in the (Re)production and Potential Revision of Gendered Ethnicities. Participations: Journal of Audience and Reception Studies 1. Available online: http:/ / www.participations.org/volume\%201/issue\%202/1_02_qureshi_article. htm (accessed on 24 January 2019).

Qureshi, Karen. 2006. Trans-Boundary Spaces: Scottish Pakistanis and Trans-Local/National Identities. International Journal of Cultural Studies 9: 207-26. [CrossRef]

Qureshi, Karen, and Shaun Moores. 1999. Identity Remix: Tradition and Translation in the Lives of Young Pakistani Scots. European Journal of Cultural Studies 2: 311-30. [CrossRef]

Renan, Ernst. 1939. What is a Nation? In Modern Political Doctrines. Edited by Alfred Zimmern. Oxford: Oxford University Press, pp. 186-205.

Revoir, Paul. 2012. Heavily Made-Up Girl in a Hijab Provokes Storm of Complaints as BBC is Accused of Insulting Muslims with New Sitcom Citizen Khan. Mail Online, August 28. Available online: http:/ / www.dailymail.co.uk/news/article-2194972/Citizen-Khan-provokes-200-complaints-BBCaccused-insulting-Muslims.html (accessed on 24 January 2019).

Roy, Olivier. 2004. Globalised Islam: The Search for a New Ummah. London: Hurst.

Roy, Olivier. 2007. Secularism Confronts Islam. Translated by George Holoch. New York: Columbia University Press.

Saha, Anamik. 2013. Citizen Smith More than Citizen Kane? Genres-in-Progress and the Cultural Politics of Difference. South Asian Popular Culture 11: 97-102. [CrossRef]

Sampson, Robert, and John Laub. 1990. Crime and Deviance Over the Life Course: The Salience of Adult Social Bonds. American Sociological Review 55: 609-27. [CrossRef]

Sampson, Robert, and William Wilson. 1995. Toward a Theory of Race, Crime and Urban Inequality. In Crime and Inequality. Edited by John Hagan and Ruth Peterson. Stanford: Stanford University Press, pp. 37-54.

Sarwar, Mohammad. 2016. My Remarkable Journey: The Autobiography of Britain's First Muslim MP. Edinburgh: Birlinn.

Shah, Bindi, Claire Dwyer, and Tariq Modood. 2010. Explaining Educational Achievement and Career Aspirations Among Young British Pakistanis: Mobilizing “Ethnic Capital”. Sociology 44: 1109-27. [CrossRef]

Sharp, Clare, Anna Marcinkiewicz, and Lisa Rutherford. 2014. Attitudes Towards Alcohol in Scotland: Results From the 2013 Scottish Social Attitudes Survey. Edinburgh: ScotCen Social Research.

Shaw, Alison. 2001. Kinship, Cultural Preference and Immigration: Consanguineous Marriage Among British Pakistanis. The Journal of the Royal Anthropological Institute 7: 315-34. [CrossRef]

Smith, David. 2005. Ethnic Differences in Intergenerational Crime Patterns. Crime and Justice 32: 59-129. [CrossRef]

Suleiman, Yasir. 2009. Contextualising Islam in Britain: Exploratory Perspectives. Cambridge: University of Cambridge, Centre of Islamic Studies.

Sunak, Rishi, and Saratha Rajeswaran. 2014. A Portrait of Modern Britain. London: Policy Exchange.

The Economist. 2009. Islam in Tartan. The Economist, May 7. Available online: http:/ / www.economist.com/node/ 13611699 (accessed on 24 January 2019). 
The Economist. 2015. The Thistle and the Crescent. The Economist, August 15. Available online: http:/ /www.economist.com/news/britain/21661000-muslims-seem-happier-identify-scottishenglish-thistle-and-crescent?zid=315\&ah=ee087c5cc3198fc82970cd65083f5281 (accessed on 24 January 2019).

The Scotsman. 2003. Scots Butcher Creates Halal Haggis for Muslim Clientele. The Scotsman, December 7. Available online: http:/ / www.scotsman.com/news/scotland/top-stories/scots-butcher-creates-halal-haggis-formuslim-clientele-1-1296802 (accessed on 24 January 2019).

Wardak, Ali. 2000. Social Control and Deviance: A South Asian Community in Scotland. Aldershot: Ashgate.

Weber, Victoria. n.d. Scottish, English, European Identities: A Literature Review. Sociology Research Papers. Edinburgh: University of Edinburgh.

Webster, Alison. 2003. The Contribution of the Scottish Enlightenment to the Abandonment of the Institution of Slavery. The European Legacy: Towards New Paradigms 8: 481-89. [CrossRef]

Weedon, Elisabet, Sheila Riddell, Gillean McCluskey, and Kristina Konstantoni. 2013. Muslim Families' Educational Experiences in England and Scotland. Edinburgh: University of Edinburgh, Centre for Research in Education Inclusion and Diversity.

Werbner, Pnina. 2012. Veiled Interventions in Pure Space: Honour, Shame and Embodied Struggles Among Muslims in Britain and France. In Islam in the West: Key Issues in Multiculturalism. Edited by Max Farrar, Simon Robinson, Yasmin Valli and Paul Wetherly. Basingstoke: Palgrave Macmillan, pp. 103-20.

Whybrow, Paul, Julie Ramsay, and Karen MacNee. 2012. The Scottish Health Survey: Equality Groups. Edinburgh: Scottish Government.

Zapata, Sarah. 2010. Contesting Identities: Representing British South Asians in Damien O'Donnell's East is East. Journal of English Studies 8: 175-86. [CrossRef]

(C) 2019 by the author. Licensee MDPI, Basel, Switzerland. This article is an open access article distributed under the terms and conditions of the Creative Commons Attribution (CC BY) license (http:/ / creativecommons.org/licenses/by/4.0/). 